\title{
Role of microorganisms in Permeable Reactive Bio-Barriers (PRBBs) for environmental clean-up: A review
}

\author{
Upadhyay S. and Sinha A.* \\ Department of Environmental Science \& Engineering, Indian Institute of Technology (ISM) Dhanbad - 826 004, Jharkhand, India \\ Received: 13/11/2017, Accepted: 31/01/2018, Available online: 18/05/2018 \\ *to whom all correspondence should be addressed: e-mail: aloksinha11@yahoo.com
}

\begin{abstract}
It is an indisputable fact that any environmental clean-up technology generating certain kind of effective result would be easily supported. One of them includes Permeable reactive bio-barrier which is an innovative technology started from 90's to treat a variety of contaminants along the natural gradient flow of groundwater through immobilization or transformation of pollutants into less toxic and harmful form. Despite of any broad acknowledgement, there are lesser known knowledge about use of microorganisms in permeable reactive barriers, mingling of microorganisms with other reactive media and their effect on each other's reactivity. The current review deals with an overview of the types of reactive media used in Permeable Reactive Barriers (PRBs) as well as different bio-barriers (PRBBs) utilized for the treatment of various contaminants, long-term performance of permeable reactive barrier and combination of microorganism and reactive media to look forward for their symbiotic relationship in permeable reactive barrier for environmental remediation.
\end{abstract}

Keywords: Permeable reactive barriers, Bio-barriers, Remediation, Reactive media

\section{Introduction}

In Past few decades, groundwater pollution has become a major environmental issue owing to industrial and agricultural applications. The pollution of groundwater resources by organic pollutants like chlorinated organic compounds, pesticides, herbicides, dyes, nitro-aromatic compounds and inorganic pollutants like heavy metals, nitrate, etc. is of paramount importance. Due to a broad range of contaminants emerging from various sources poses a grave threat to the quality of groundwater (Schipper et al., 2010; Wiafe et al., 2013; Rodak et al., 2014). Earlier 'pump-and-treat' has been used for the remediation of contaminated groundwater. In pump-andtreat system, the contaminated groundwater is extracted from the subsurface by pumping, and then it is treated before being discharged to the environment. The treated water is then pumped back to the subsurface. Because of limitations like the long time to meet clean-up goals and high cost this technique fails to work correctly. Apart from these techniques, various physical and chemical treatment methods like adsorption, coagulation, precipitation, filtration, and advanced oxidation systems have been applied for the treatment of contaminants. Research has been ongoing to meet eco-friendly and sustainable remediation approach (Henderson and Demond, 2007).

An innovative in situ remediation technique known as Permeable reactive barriers (PRBs) technology is accepted worldwide for remediation of contaminated groundwater (Tratnyek, 2003). The reactive media is placed perpendicular to the flow of contaminated groundwater in PRB system. The mechanism behind the treatment of contaminants involves the reaction of contaminants with the reactive media thus generating lesser toxic compounds or infatuation to reactive media. The transformation of highly toxic contaminated groundwater to less toxic form usually takes place inside the barrier or downhill of the wall which is mainly dependent on the type of reactive media used for different kinds of contaminants and the process is generally accomplished by exterminatory and/or nonexterminatory processes (Chen et al., 2011a). However, the reactions within the permeable reactive barriers may be impacted by the presence of micro-organisms within the barrier.

A lot of review paper is published on PRB focusing on different reactive media, advantages, and disadvantages of PRB, and performance of PRB (Henderson and Demond, 2007; Noubactep, 2010; Obiri et al., 2014). This paper portrays on efficiencies of different reactive media along with their limitations, modification in technology, with particular emphasis on the effect of biodegradation within the PRB system with various types of microbes, reported till date.

\section{Reactive media used in PRBs}

The reactive media zone is the place in the PRBs where contaminants are removed relying on the kind of reactive material used for different type of pollutants. In some PRBs, contaminants are removed by corporal contact while others remove contaminants by changing the biogeochemical processes in the treatment zone, thus providing suitable conditions for contaminant removal or biodegradation. Apart from the design, PRBs primary purpose is to transport the contaminants keen on to the 
reactive zone, where the degradation process can take place. The most common reactive material used is ZeroValent Iron (ZVI). Besides $\mathrm{ZVI}$, the range of reactive material includes zeolites, oxygen releasing compounds (ORC), activated carbon (AC), peat, sawdust, etc. for the removal of contaminants. The major disadvantage with such type of reactive materials is that they confined to a small cluster of contaminants, and their accessibility is also challenging, and they are expensive too (Kober et al., 2002). The replacement of these reactive materials is still in progress that is not limited to a particular group of contaminants rather that is applicable for a large group of contaminants within PRB (Di-Nardo et al., 2010). Ruhl et al., (2013) performed an experiment for the removal of TCE using a combination of $\mathrm{Fe}(0)$ with additional reactive materials in PRB. The reactive media consists of $\mathrm{Fe}(0)$, Granulated ferric hydroxide (GFH), Calcite and wood chips. The contaminant removal observed in $184 \mathrm{~d}$ having $\mathrm{Fe}(0)$ and $\mathrm{GFH}$ as reactive media and the reactivity decline thereafter. A complete transformation of TCE to CDCE found with an elevated concentration of $\mathrm{CDCE}$. The use of reactive material generally depends on:/ (i) different category of contaminants along with their concentrations to be treated (i.e., organic and/or inorganic), and mechanisms involved in their removal (e.g. sorption, biodegradation, or precipitation) (ii) aquifer hydrogeological and biogeochemical conditions (iii) what are the impacts on environmental/ health; (iv) mechanical stability and (v) the availability and cost of the material. There may be different types of processes for the removal of contaminants, but the dominant removal mechanism involves (i) destructive biotic or abiotic processes such as e.g. complete biodegradation or reductive dechlorination of contaminants into utterly new non-toxic products; (ii) nondestructive processes e.g. surface complexation, adsorption, cation exchange, and precipitation that clutch the contaminants and accordingly reduce their concentrations in the groundwater. It should be taken into consideration that reactive materials that precipitate or immobilize Contaminants must have some properties that adjust geochemical parameters such as $\mathrm{pH}$ and redox of the aquifer so that solubility of the contaminants gets reduced or minimize (Panturu et al., 2009). The removal processes in PRBs are dependent on the type of media used, the target contaminants that are to be degraded as well as the biogeochemical conditions prevailing in the aquifer. Table 1 sums up the various reactive materials used for remediation of different type of contaminants in PRBs. Table 2 summarize the locations where PRB have been installed and running successfully.

Table 1. Different types of reactive media used in PRB

\begin{tabular}{|c|c|c|c|c|c|c|}
\hline $\begin{array}{c}\text { Reactive } \\
\text { media }\end{array}$ & Contaminants type & Mechanism & Efficiency & $\begin{array}{c}\text { Optimal } \\
\text { condition }\end{array}$ & Limitations & References \\
\hline ZVI & $\begin{array}{l}\text { Chlorinated } \\
\text { Hydrocarbons, Heavy } \\
\text { metals, Metalloids, radio- } \\
\text { Nuclides,Nutrients, } \\
\text { Pesticides }\end{array}$ & $\begin{array}{l}\text { Adsorption, Surface } \\
\text { complexation, } \\
\text { Reductive } \\
\text { precipitation, Co- } \\
\text { precipitation }\end{array}$ & $90-99 \%$ & - & $\begin{array}{l}\text { Easily oxidized } \\
\text { \& increases } \\
\text { the pH which } \\
\text { induces } \\
\text { corrosion \& } \\
\text { leads to poor } \\
\text { permeability } \\
\text { of reactive } \\
\text { material }\end{array}$ & $\begin{array}{c}\text { Yang et al., } \\
\text { 2010b; } \\
\text { Naryko et } \\
\text { al., } 2014\end{array}$ \\
\hline $\begin{array}{c}\text { Activated } \\
\text { Carbon }\end{array}$ & Phenols, PCE,TCE, BTEX & Sorption & - & - & $\begin{array}{l}\text { Rapid } \\
\text { breakthrough } \\
\text { \& surface } \\
\text { coating lead } \\
\text { to decrease in } \\
\text { sorption } \\
\text { capacity }\end{array}$ & $\begin{array}{c}\text { Di-nardo et } \\
\text { al., } 2010\end{array}$ \\
\hline Zeolite & $\begin{array}{l}\text { Heavy metals, } \mathrm{NH}_{4}{ }^{+} \text {, } \\
\text { Radionuclides, PCE \& BTEX }\end{array}$ & $\begin{array}{l}\text { Sorption, Ion } \\
\text { exchange, } \\
\text { precipitation }\end{array}$ & $80-100 \%$ & $\begin{array}{l}\text { pH value must } \\
\text { be in the range } \\
\text { of } 3-11\end{array}$ & - & $\begin{array}{l}\text { Perric et al., } \\
2004\end{array}$ \\
\hline Apatite & Lead, heavy metals, U(VI) & $\begin{array}{l}\text { Sorption,preci- } \\
\text { pitation,surface } \\
\text { Adsorption, } \\
\text { incorporation }\end{array}$ & - & Low pH & - & $\begin{array}{c}\text { Naryko et } \\
\text { al., } 2014\end{array}$ \\
\hline TRM & AMD, $\mathrm{Fe}, \mathrm{Cu}, \mathrm{Zn}, \mathrm{Ni} . \mathrm{Pb}, \mathrm{Cr}$ & $\begin{array}{l}\text { Adsoprtion, } \\
\text { precipitation }\end{array}$ & $97-99 \%$ & $\begin{array}{l}\text { Due to fine } \\
\text { texture,it should } \\
\text { be mixed with } \\
\text { sand or gravel to } \\
\text { inc rease } \\
\text { permeability of } \\
\text { PRB }\end{array}$ & - & $\begin{array}{l}\text { Munro et } \\
\text { al., 2004; } \\
\text { laponite et } \\
\text { al., } 2006\end{array}$ \\
\hline
\end{tabular}


Table 2. Locations of various installed PRBs

\begin{tabular}{ccccc}
\hline PRB with reactive & $\begin{array}{c}\text { Installation in different } \\
\text { country }\end{array}$ & $\begin{array}{c}\text { Types of contaminants } \\
\text { removed }\end{array}$ & Configuration & References \\
\hline $\begin{array}{c}\text { GAC, Zeolite } \\
\text { Limestone \& } \\
\text { Crushed concrete }\end{array}$ & Casey station Antarctica & Petroleum hydrocarbon & Funnel \& Gate & Mumford et al., 2014 \\
\hline Granular iron & California & Fe(II) \& Mn(II) & Wang et al., 2016 \\
\hline $\begin{array}{c}\text { Granular iron } \\
\text { Activated carbon }\end{array}$ & $\begin{array}{c}\text { Elizabeth city, North } \\
\text { Carolina }\end{array}$ & Cr(VI) \& TCE & Gate and \\
Continuous wall & Jeen et al., 2011 \\
\hline $\begin{array}{c}\text { Grey cast-Fe with } \\
\text { gravel }\end{array}$ & Willisau,Switzerland & PCE \& TCE & Wilkin et al., 2014 \\
\hline GAC & Canadian arctic & Chromate & - & Erto et al., 2014 \\
\hline
\end{tabular}

\section{Bacterial Biobarriers as treatment zone in PRB}

Application of biobarriers in the PRBs as a treatment zone contains those materials that are capable of stimulating or enhancing microorganisms to demean contaminants anaerobically or aerobically. Such barriers are termed as Permeable Reactive Bio-Barriers (PRBB). Since PRBBs are dependent on the use of microorganisms for degradation of contaminants, it is advisable to use the suitable population of microorganisms for a particular pollutant. The microbes are often ever-present, particularly in the upper layers of the aquifer, so it is quite easy to use them for removing contaminants (Di-Nardo et al., 2010; ITRC, 2011). In this technology, the microorganisms that are used as a reactive medium to debase or alleviate the contaminants are clung to a porous support (Tiehm et al., 2008). The main restrictions on this type of approach are that the microorganisms or consortium must form biofilm with the degradative ability for the target pollutants on the reactive materials in PRBB. Microorganisms undergo degradative mechanism by two ways mentioned below:

\subsubsection{Aerobic Degradation in PRBBs}

Via aerobic biodegradation, removal of some organic contaminants takes place. Such contaminants like petroleum hydrocarbons (such as BTEX and MTBE) have mostly reducing nature. The need for the terminal electron acceptors (TEAs) to stimulate such type of processes from the contaminants that transfer electrons during their degradation is very imperative. $\mathrm{O}_{2}, \mathrm{NO}_{3}{ }^{-}, \mathrm{CO}_{2}$, sulfate, manganese, and ferric iron are the usually present TEAs in the environment. Among the available TEAs, molecular oxygen is, however, more often preferred to other TEAs because of its high energy yielding capacity to the microbes which is, in turn, is helpful in stimulating degradation of contaminants. There are some other oxygen and nitratereleasing compounds (ORC) such as calcium peroxide, magnesium peroxide, hydrogen peroxide, and sodium percarbonate that have been used to liberate oxygen or create an aerobically active zone in the subsurface. Due to the low cost of ORCs, it has been used mostly in PRBs (Simon and Meggyes, 2000; ITRC, 2011). Mackay et al., (2002) performed two sets of an experiment to treat Methyl tert-butyl ether (MTBE) in contaminated groundwater at two sites in California using native and nonnative bacterial strain, and they found that diffusive release of oxygen into the groundwater or oxygen released through sparging can degrade MTBE aerobically by natvive microorganism. The result confirmed the biodegradation activity occurred because of direct supply of oxygen through polymeric tubing and air sparging. Aerobic degradation of BTEX contaminated groundwater was also carried out by (Yeh et al., 2010) with column experiments, batch experiments, and bench-scale permeable reactive barrier (PRB) using microbial community obtained from industrial wastewater treatment sludge and organicscontaminated groundwater site in central Taiwan. To provide an aerobic condition for degradation, various amount of $\mathrm{CaO}_{2}$ added. The experimental result showed that in the batch experiment the degradation was $80 \mathrm{mg}$ $\mathrm{I}^{1}$. The PRB system shows removal efficiency in the following ascending order: ethylbenzene > toluene> $p$ xylene $>$ benzene during 100 days of operation. Shock load applied on day 44 and 52 for 4 hrs with an increase in BTEX concentration from $30 \mathrm{mg} \mathrm{I}^{-1}$ to $60 \mathrm{mg} \mathrm{I}^{1}$ and the level reduced to the original. The addition of oxygen releasing compounds like $\mathrm{CaO}_{2}$, is of the reason that it could meet the oxygen requirement of bacteria. However, shock loading exerts a negative impact on microbial community thereby reducing their degradation capability.

\subsubsection{Anaerobic Degradation in PRBBs}

In contrast with the contaminants that are aerobically biodegraded, anaerobically degradable contaminants are oxidized in nature and thus are sooner degraded by reduction. The reactive materials used in PRBs serves as a source of electrons whereas the contaminants that are degraded serve as the electron acceptors for the metabolic process of microorganisms (Obiri et al., 2014). Nitrate, sulfate, carbon dioxide, ferric iron etc. acts as electron acceptors to mediate anaerobic degradation. Materials like $\mathrm{ZVI}$, dithionite may act as reactive barrier materials which can facilitate the anaerobic degradation of contaminants.

\subsection{Fungus Biobarriers}

Another group of microorganisms has identified by researchers known as, Fungi having higher potential in bioremediation processes because they can degrade a wide variety of organic compounds by co-metabolism under oxic conditions. Specifically, white-rot fungi (WRF) have been known to degrade several xenobiotic 
compounds at broader scale. Folch et al., (2013) used fungus as biobarrier to remediate groundwater in an artificial aquifer. Fungus Trametes versicolor, was used to treat Orange $\mathrm{G}$ dye contaminated groundwater. The result of the study revealed that the maximum degradation was $97 \%$ and the degradation continues to $85 \%$ for about eight days. The results showed that fungus could be used as an active media in PRB.

\section{Degradation of Contaminants in PRBBs}

\subsection{Nitrate}

The presence of some low-cost organic materials for the removal of nitrate from groundwater includes sewage sludge, leaves, sawdust, peat, alfalfa, manure, wood waste and compost (Schipper et al., 2010; ITRC, 2011). But there are some microorganisms like denitrifying bacteria such as Paracoccus denitrificans and other microorganisms belonging to the Pseudomonas group in the presence of organic substrates which are efficient in removal of nitrate. A two layer heterotrophic - autotrophic denitrification PRB was installed by Huang et al., (2015) for the treatment of nitrate- nitrogen contaminated groundwater having pine bark as an upper layer and spongy iron and river sand mixture as the lower layer. The removal mechanism involves biological deoxygenation, heterotrophic denitrification, hydrogenotrophic denitrification, and anaerobic Fe corrosion. Both batch and column experiments conducted and the result showed that the removal efficiency continues up to $504 \mathrm{~d}$ having removal of 91\%. The NO3- $-\mathrm{N}$ degradation was achieved at first $65 \mathrm{~cm}$ of the column having influent concentration of 23 and 46 $\mathrm{mg} \mathrm{\textrm {L } ^ { - 1 }}$ whereas $79 \%$ was depleted having influent concentration of $103 \mathrm{mg} \mathrm{L}^{-1}$. The presence of aerobic heterotrophic bacteria depleted oxygen via aerobic respiration and thus favoring hydrogenotrophic denitrification by providing excess $\mathrm{CO}_{2}$.

\subsection{Sulfate and Heavy Metals}

Reduction of sulfates to sulfides by Sulfate Reducing Bacteria (SRB) utilizes the organic substrates under anaerobic conditions (Waybrant et al., 2002). Generation of dissolved phosphates by reduction process is further taken up by microbes as their nutrient sources that are involved in degradation and thus accelerating $\mathrm{pH}$. Precipitation of heavy metals as metal sulfides can occur under quite elevated $\mathrm{pH}$ conditions, as the reaction of sulfides can take place subsequently with heavy metals. Sulfate reduction by microbes was achieved by $\mathrm{H}_{2}$ production ( $\mathrm{FeO}$ oxidation) and the presence of bacterial species like Desulfosporosinus, that uses $\mathrm{H}_{2}$ production as an energy source. One of the results showed the advantage of $\mathrm{Fe}^{0}+\mathrm{SRB}$ integrated systems over conventional $\mathrm{FeO}$ based system regarding precipitate stability. The combination of $\mathrm{FeO}$ and microbial activities could enhance the treatment capability of PRBs and produce stable precipitates of Zn (Kumar et al., 2015). Zn removal in integrated system $\mathrm{Fe}^{0}+\mathrm{SRB}$ system can be succeeded by two ways i.e. initially $\mathrm{Zn}$ can be removed via Ferrite- $\mathrm{Zn}$ formation reflecting adsorption of $\mathrm{Zn}$ on $\mathrm{Fe}^{0}$ surface and later on activation of microbial sulfate reduction by possible interaction of $\mathrm{Zn}$-Fe-S. The result obtained showed the overall activity of $\mathrm{Fe}^{0}$ and $\mathrm{SRB}$ by removing the dissolved contaminants, and SRB thus fix metals as stable metal sulfides meanwhile $\mathrm{Fe}^{0}$ provides $\mathrm{H}_{2}$ as an electron donor which stimulates growth of SRB.

\subsection{Chlorinated Solvents}

Ozturk et al., (2012) investigated by batch and column experiments to degrade Trichloroethylene (TCE) in groundwater with the use of commercial compost and eucalyptus mulch and the result showed that the decomposition rates were 0.23 and $1.2 \mathrm{~d}^{-1}$ in mulch and compost respectively and this shows that highly organic natural media developed a bioactive zone which allows the anaerobic decomposition of TCE. Mondal et al., (2016) did an experiment to evaluate the degradation efficiency of peat and sawdust as reactive media in PRB for TCE. The experiment was conducted in a laboratory batch microcosm and flow through the column and the result showed that peat was quite capable in biodegradation of TCE to ethene in a contaminated soil than sawdust. The findings concluded that peat completely supports reductive dechlorination of TCE and can slowly release electron donor source. Another is that peat can have lower biological growth and methane production compared to sawdust.

\subsection{Hexavalent chromium}

Liu et al., (2015) conducted an experiment to treat Cr (VI) contaminated groundwater with immobilization of $\mathrm{Cr}(\mathrm{VI})$. The results of the experiment showed that $\mathrm{pH}$ had a significant influence on the removal of $\mathrm{Cr}(\mathrm{VI})$. The removal efficiency decreased with increase in $\mathrm{pH}$ from 5.5 to 9.0. An experiment was conducted in a column reactor by (Boni and Sbaffoni, 2009) for the removal of $\mathrm{Cr}$ (VI) from contaminated groundwater by compost based biobarrier comprising of green compost and siliceous gravel as a reactive media. Almost $99 \%$ of $\mathrm{Cr}(\mathrm{VI})$ removed during the whole activity. The removal mechanism involved in this process was adsorption on the organic-based matrix and reduction of $\mathrm{Cr}$ (VI) into $\mathrm{Cr}$ (III) by anaerobic bacteria present in green compost. The involvement of siliceous gravel in removal process was negligible as only used as the structure matrix. $\mathrm{Cr}$ (III) was entrapped in the solid matrix as is not detected in the outlet. A contaminated water was containing $\mathrm{Cr}(\mathrm{VI})$ as a contaminant was treated by (Pagnanelli et al.2012) with sulfate reducing bacteria fed with ethanol. This biological treatment performed in a fixed bed reactor with sulfate reducing bacteria as reactive media. Two fixed bed column reactors used in which one supplied with SRB and other used as a blank. Both the reactors continuously fed with a synthetic solution containing ethanol, $\mathrm{Cr}(\mathrm{VI})$ and sulfate. The result obtained showed that inoculated column removes $65 \pm 5 \%$ of sulfate and $95 \pm 5 \%$ of chromium removed due to a biological mechanism. Ethanol serves to be a better alternative to common electron donors and carbon source for SRB growth.

\subsection{Hydrocarbons}


Among various microorganisms used for the treatment of contaminants, Arthrobacter species are of particular interest because they are highly efficient for bioremediation. These bacteria can detoxify metal wastewater by two mechanisms: either by reduction or accumulation inside the cells and/or adsorption on their surface (Blazquez et al., 2009). Furthermore, several strains of this genus have been identified in degradation of aromatic compounds which include 4-fluorophenol, 4chlorobenzoate, phenol, p-hydroxybenzoic acid and monoand dichlorinated biphenyls (Ferreira et al. 2008; Karigar et al. 2006). Amongst various identified strains, the species Arthrobacter viscosus have high potential as bioreactive medium in the PRBBs for many of the organic compounds such as diethylketone, phenol, chlorophenol, o-cresol (Costa et al., 2012; Quintelas et al., 2010) as well as metals (Lameiras et al., 2008; Pazos et al., 2010). Besides their degradation potential, $A$. viscosus, a non-pathogenic bacterium releases a high amount of viscous extracellular polysaccharides (Lopez et al., 2003). The more the release of viscous extracellular polysaccharides the more is the holding capacity of different support structures favoring its use as a bioreactive medium. Some of the microorganisms belonging to the genus Acidovorax were also identified as degraders of polycyclic aromatic hydrocarbon (PAH) and were also used in treatment of contaminated soil at laboratory scale (Singleton et al., 2013). Other abundant bacteria enriched were Pseudoxanthomonas, Bdellovibrio, and Serpens in which Pseudoxanthomonas genus was able to degrade $\mathrm{PAH}$ also, and several other strains were isolated from contaminated soil and sediment (Klankeo et al., 2009; Patel et al., 2012). Hydrocarbons have been widely degraded by a variety of microorganisms in both conditions whether aerobic or anaerobic having different electron acceptors (Kleinsteuber et al., 2012; Hyman, 2013). Hydrogenophaga flava ENV735 was identified to degrade both TBA and MTBE in pure culture as well as enriched both in bioreactors and in microcosms (Raynal and Pruden, 2008; Bastida et al., 2010). It has observed by many researchers that Hydrogenophaga was able to degrade PAH with a mixture of toluene and benzene as a carbon source and BTEX contaminated groundwater as a source of innoculum (Aburto and Peimbert, 2011, Martin et al., 2012). Another species Pseudoxanthomonas spadix BD-a59 discovered which was able to degrade all the BTEXs (Kim et al. 2008). A BTEX fed reactor was enriched with another type of species namely Bdellovibrio for water treatment (Li and Goel, 2012), and for the first time, Serpens genus has been used for hydrocarbon degradation. Thauera aromatica K 172, a member of Serpens genus has the better ability to degrade aromatic hydrocarbons under aerobic and denitrifying conditions (Anders et al., 1995). It has also found that Thauera with toluene as carbon source best suited under denitrifying conditions. (Li et al., 2012). Some of the work carried out by some researchers in BTEX contaminated groundwater and the result found was that Mycobacterium sp. C3 was able to degrade both toluene and m-xylene, (Cavalca et al., 2004). Some of the other microorganisms belonging to the genus Azoarcus were reported to degrade hydrocarbons in nitrate-reducing conditions. Table 3 summarizes various micro-organism utilized for remediation of contaminants in PRBBs.

Table 3. Microorganisms used in PRBBs for removal of contaminants

\begin{tabular}{|c|c|c|c|c|c|c|c|}
\hline $\begin{array}{c}\text { Microorganims used in } \\
\text { PRBs }\end{array}$ & $\begin{array}{c}\text { Types of } \\
\text { contaminants }\end{array}$ & $\begin{array}{l}\text { Removal } \\
\text { efficiency }\end{array}$ & Time & Temperature & pH & Experiment & References \\
\hline Trametes versicolor & Orange $\mathrm{G}$ dye & $97 \%$ & 159hr & $15^{\circ} \mathrm{C}-25^{\circ} \mathrm{C}$ & $6-7$ & lab-scale & $\begin{array}{c}\text { Folch et al., } \\
2013\end{array}$ \\
\hline $\begin{array}{c}\text { Delftia sp.lpo (KR } \\
\text { 673339) and } \\
\text { Pseudomona sp.wyj10 } \\
\text { (KR 673340) }\end{array}$ & $\begin{array}{c}\text { Aniline and Nitro } \\
\text { benzene }\end{array}$ & $98 \%$ & $25 d$ & $10^{\circ} \mathrm{C}$ & - & - & $\begin{array}{c}\text { Wen et al., } \\
2015\end{array}$ \\
\hline $\begin{array}{c}\mathrm{p}-\mathrm{CNB}-\text { reducing } \\
\text { bacteria }\end{array}$ & $\begin{array}{c}\text { pentachloronitro } \\
\text { benzene }\end{array}$ & $95 \%$ & $48 \mathrm{hr}$ & - & 8.0 & - & $\begin{array}{c}\text { Yin et al., } \\
2012\end{array}$ \\
\hline Arthrobacter viscosus & $\begin{array}{c}\text { Polycyclic } \\
\text { aromatic } \\
\text { hydrocarbon } \\
\end{array}$ & $80 \%$ & $4 d$ & - & $8-9$ & Bench scale & $\begin{array}{c}\text { Ferreira et } \\
\text { al., } 2013\end{array}$ \\
\hline Arthrobacter viscosus & Chromium VI & $79 \%$ & $18 d$ & - & $5.6-6.4$ & - & $\begin{array}{c}\text { Fonseca et } \\
\text { al., } 2012\end{array}$ \\
\hline Thiobacillus bacteria & Nitrate & - & $48 \mathrm{~h}$ & - & - & $\begin{array}{c}\text { Batch } \\
\text { experiment }\end{array}$ & $\begin{array}{c}\text { Li et al., } \\
2016\end{array}$ \\
\hline
\end{tabular}

\section{Modifications in the PRB technology}

The treatment of chlorinated solvents such as trichloroethylene (TCE), the three isomers of DCE (1,2-cis-, 1,2-trans- and 1,1-DCE) and vinyl chloride (VC) contaminated groundwater first conducted within PRB. The PRB technology being effective for the treatment of compounds like TCE, DCE, and VC, its use was further elaborated to remediate other contaminants also. The types of PRBs mainly used for field application are the funnel-and-gate and the continuous gate designs (Thiruvenkatachari et al., 2008). The funnel-and-gate design consists of two structures: the funnel, comprising of cut-off walls used to join the contaminant to the zone of treatment, and the reactive gate used for the treatment process. However, the funnel-and-gate PRB system is quite expensive to construct; it treats some of extensively dispersed plumes.

On the other hand, the continuous gate PRB system consists of transverse treatment barriers to the path of 
contamination. The advantage of this PRB system is that it is cost effective; simple to construct and possess modest effect on the flow of groundwater. But the limitation with this type of system is that only plumes with narrow widths are suited for treatment and bypass of contaminated water may pose problems. Earlier the use of zero-valent iron (ZVI) in the PRB system was limited for some of the contaminants. For avoiding this problem, the concept of biobarrier introduced which uses organic materials for the remediation of contaminants that has not removed by the use of reactive materials like $Z \mathrm{VI}$ in the PRBs. With the use of biobarriers in PRBs, the growth and activities of microorganisms for degrading contaminants gets enhanced as it became easier to use cost-effective substrates/organic materials as filling materials (Vesela et al., 2006).

Earlier the PRBs were seen to have a single barrier (with a single reactive material) (ITRC, 2011). The single barrier system treats only one type of contaminants or contaminants of comparable characteristics (e.g. heavymetals). The major disadvantage with single barrier system was that the system was quite inefficient to treat contaminants of different properties having different physical, chemical and thermodynamic properties (e.g. heavy-metals, BTEX and TCE) (Kober et al., 2002). Besides the incapability of such barriers to treating multicontaminants, research has been going on to deal with the problem of pollutant mixing, which is the headless generation of new potentially hazardous contaminants while removing other contaminants (Stevens and Quinton, 2009; Healy et al., 2012). However, in the path of increased global environmental concern and use of sustainability approach for remediation, pollutant swapping has become a major concern. For such problem, a concept of the multibarrier system (Figure 1) has set up which make PRBs a more suitable and sustainable approach and which broadens their applicability to a larger extent. A multibarrier PRBs consists of two or more than two barriers with similar or different types of reactive materials (sequenced multi-barrier). However, it can also be defined as a single barrier filled with different types of reactive materials (a mixture of reactive materials or multi-treatment barrier) (Obiri et al., 2014).

Some multi-barriers have been limited to treat mainly organic contaminants. A study conducted by (Teerakun et al., 2011) to address TCE with conjugation of ZVI and biobarrier in synthetic groundwater. The three-barrier system installed in which the first column filled with iron fillings, the second column with sugarcane baggase mixed with anaerobic sludge as an anaerobic barrier and the third one with biofilm coated on oxygen carbon inducer releasing material as an aerobic barrier. The fourth column installed with sand to evaluate the performance of TCE and its metabolites down gradient of the system. The removal mechanism includes chemical and biological processes in which the overall removal was $84 \%$ and the removal by individual column was iron fillings $42 \%$, anaerobic barrier $16 \%$ and aerobic barrier $25 \%$ respectively. The breakdown of TCE into different metabolites showed the degradation of the column system. Morkin et al., (2000) reported the use of two barriers for the treatment of a mixture of chlorinated ethenes (DCE and VC) and BTEX within a funnel-and-gate system. The first barrier was filled with granular iron for reductive dechlorination, whereas the second was a biobarrier which allows for degradation of the contaminants by biological means, mainly BTEX and the by-products of the chlorinated ethenes. Lee et al., (2007) also used a multibarrier PRB system filled with iron and a biobarrier filled with the biologically active tire to remove PCE, TCE, and organic matter. Kober et al., (2002) used Fe0 and granular activated carbon (GAC) as reactive materials for the treatment of multifaceted contaminant mixtures in groundwater.

Van-Nooten et al., (2010) also combined different reactive materials and for removing a composite mixture of organic and inorganic contaminants consisting of, adsorbable organic halogens (AOX), chemical oxygen demand (COD), ammonium and the by-products of nitrification and denitrification. Apart from costs, the multi-treatment system has various complexities in design and also has difficulties in monitoring them holistically. To address such type of issues, some approaches and innovation in technology are being used to make the system more suitable and sustainable. Various studies have often been carried out to get information about different microbiological and geochemical treatment facts in such treatment systems to make it more efficient.

To analyze and predict variations in an assortment of parameters such as changes in $\mathrm{pH}$ and Eh of groundwater from the reactions between the reactive materials, the contaminants and the groundwater elements, sequencing of barriers, type of reactive materials, tools like MINTEQA2 (Allison et al., 1991) and PHREEQC (Parkhurst and Appelo, 1999) are also being used. Healy et al., (2012) reported that certain factors need to assess for pollution swapping problem and the risk associated with the release of greenhouse gases (GHG) and generation of dissolved contaminants in bioreactors.

Recently, Fenton et al., (2014) recommended that using microbial and molecular fingerprinting as an in-situ costeffectual tool can assess balancing of nutrient and gas in PRBs. Some researchers have reported that while treating contaminants or the usefulness of PRBs with respect to time has shown to be ineffective because of the interaction between reactive media, contaminant and aquifer properties inside or up-gradient of the barriers. The reason behind PRB failure is an accumulation of precipitates of carbonates and sulfates, failure in reactivity and decline in hydraulic residence time, production of gas following a reduction in permeability, and competition for or loss of reactive sites due to corrosion, fouling or precipitation. Henderson and Demond, (2007) did a critical review to know the long-term performance of PRBs filled with ZVI using statistical and graphical methods and tools to recognize the most significant factors that affect the prolonged existence of barriers. Their study discovered that indecent hydraulic depiction was the prime factor that led to failure of most PRB. 


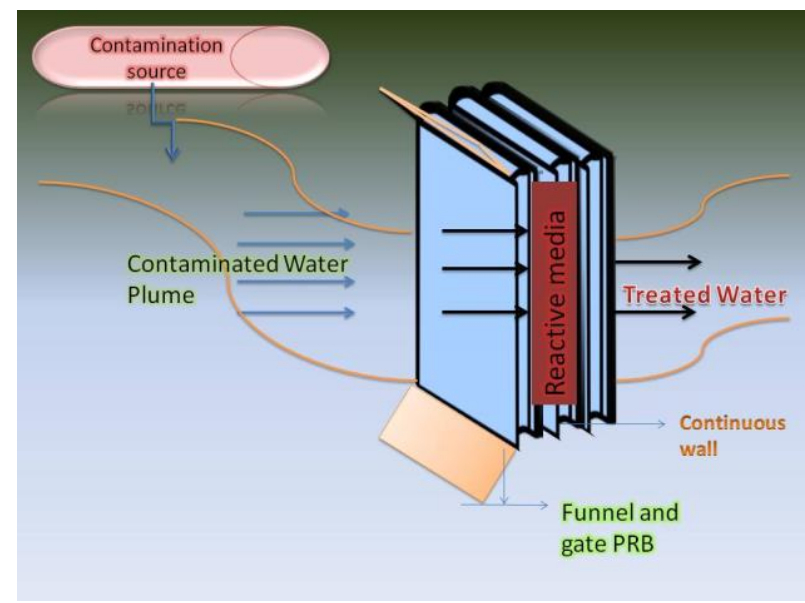

Figure 1. Schematic diagram of Multibarrier PRB

A concept of an enricher reactor (ER) - PRBB in the batch process has been successfully applied to treat contaminated groundwater (Kasi et al., 2013). ER is an offline reactor in which bacterial culture is inoculated to target compound(s) and is used to supplement the main treatment system, such as PRBB. Appropriate growth conditions maintained for culture enrichment, such as availability of nutrients and target compounds, and suitable environmental conditions ( $\mathrm{pH}$ and temperature) monitored in the ER in order to get the desired degradation capability.

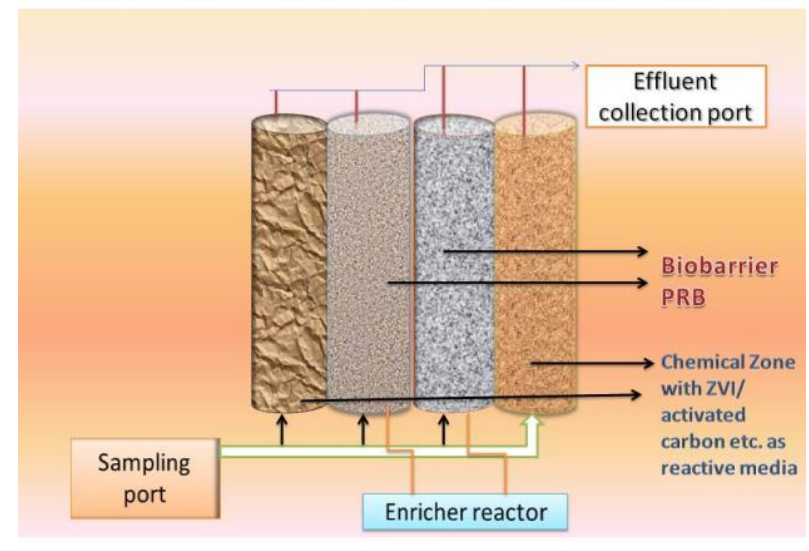

Figure 2. Concept of ChemBio-PRBB/BS with Enricher reactor

A treatment system designed in combination with chemical-biological hybrid PRB and bio-sparging (ChemBio-PRB/BS) reactive zones with a series of different media in the reactive wells and indigenous bacteria belonging to Delftia species and Pseudomonas species for the treatment of nitrobenzene and aniline contaminated groundwater (Wen et al., 2015). The two strains were able to degrade $98 \%$ organic within $72 \mathrm{~h}$ at $10{ }^{\circ} \mathrm{C}$ which shows that the present strains can degrade even at low temperature. The chemical-biological hybrid PRB shows degradation of $91 \%$ aniline and $85 \%$ nitrobenzene respectively up to 40 days, and after 40 days of treatment, the reactive media were further replaced so maintain the efficiency (Figure 2).

\section{Long-term performance of PRB}

PRB containing different types of reactive media have been gaining a lot of attention for treatment of a variety of contaminants for different time intervals. The most common reactive media used in PRB is iron, which is studied by many researchers that it may experience stabilization and reduction in permeability due to inflation of precipitates (Agrawal et al., 2002; Klausen et al., 2003). An experiment was conducted by (Suk et al., 2009) to evaluate the long- term performance of iron PRB through column experiments and numerical simulation. The research carried out with four types of iron materials having a different configuration for the degradation of cisDCE and performance of Column bearing iron materials. The result showed that one of the iron material namely ISPAT having higher corrosion rate was showing reduced degradation of cis-DCE and earliest breakthrough and poor performance in comparison with other iron material namely, Connelly iron having lower corrosion rate. The reduction in porosity was observed at five years due to the accumulation of precipitates because of higher corrosion rate than with those having lower corrosion rate. This type of study was also suggested by (Jeen et al., 2007a) that iron material bearing high corrosion rate are not so much beneficial for long term use in PRB as the performance may get hindered by precipitates. Yang et al., (2010) did an experiment to remove 2,4-dichlorophenol with the help of modified GAC and original GAC through PRB system and found that removal efficiency was quite higher with modified GAC than original GAC which could consistently improve the performance of PRB system. A calcium carbonate based PRB was installed for iron and manganese groundwater remediation at landfills by Wang et al., (2016), and they found that total iron removal was $91 \%$ during the first year of installation. But the performance of PRB began to decrease during the third year. Another column experiment was performed by Wang et al., (2013c) which showed that removal efficiency of $\mathrm{Fe}$ and $\mathrm{Mn}$ decreased with an increase in $\mathrm{pH}$ over the year because of mineral precipitates accumulated over the surface of walls of PRBs. At the end of the third year, iron-rich soil/mud coating observed on the surface of the calcium-carbonatebased material (CCBM). Yin et al., (2015) performed the removal of nitrobenzene (NB) in two columns i.e. abiotic column having a mixture of sand and iron and biotic column having a mixture of sand and iron along with NB reducing culture. They also demonstrated the longevity of the two columns used and found that biotic columns are having $60 \%$ longer life span than the abiotic column and significant amount of physical NB removal because particular iron reducing bacteria could diminish the ferric oxide formation by reducing $\mathrm{Fe}^{3}+$ to $\mathrm{Fe}^{2+}$. Hana et al., (2016) performed an experiment using acid washed zero valent iron and aluminum mixture in PRB for the removal of various heavy metals and found out that ZVAI and ZVI together have better removal efficiency than used alone with the removal efficiency of $99.5 \%$ at $300 \mathrm{hr}$. Also, fewer oxides were 
formed on the surface of acid washed ZVAI and ZVI than unacid-washed ZVAI and ZVI. Also, there was an effect of $\mathrm{pH}$ on the performance of PRB as in this while increasing the initial $\mathrm{pH}$ from 3.0 to 7.0 the removal efficiency of PRB increased because of formation of hydroxide precipitates which favors the abolition of heavy metals along with reduction and absorption. The long-term performance of PRB was also investigated by (Moraci and Calabro, 2010) having heavy metal contamination and ZVI and pumice as reactive media. The test performed for columns having aqueous nickel and copper solutions of varying concentration. The three sets of columns comprise of ZVI alone, a granular mixture of $\mathrm{ZVI}$ and pumice and pumice in series with ZVI and also in later case the pumice was placed downstream of ZVI so that pumice efficiency could also be analyzed. The results demonstrated that copper removal efficiency was high among all the set-ups, but the best performance came out of ZVI-pumice mixture and the concentration of copper was below detection limit, but the performance of $\mathrm{ZVI}$ alone ceases at the end. The reason behind ZVI-pumice best performance may be that pumice is not inert with heavy metal, and it enhances the reactivity of $\mathrm{ZVI}$. The reaction products stored in pumice pores from where they remove the pollutants by reduction, adsorption or co-precipitation. The removal of nickel was maximum at 30:70 ZVI-pumice mixture. The overall result indicated that ZVI-pumice mixture was better in the removal of contaminant and also has long-term performance throughout.

\section{Symbiotic relationship between microorganisms and reactive media}

Reactive media used along with microorganisms exerts symbiotic relationship, and various experimental results showed their interaction in PRB. Parra et al., (2016) performed another experiment to look for the effect of reactive media on microorganism in the degradation rate. The study was conducted to treat acid rock drainage containing sulfuric acid and heavy metals (copper, cadmium, and lead) using sulfate-reducing bioreactor with ZVI by flow-through column in a laboratory-based test. The continuous -flow bioreactor comprises of ZVI, limestone or a mixture of limestone and ZVI. The sulfate reduction by ZVI column was 40 to $50 \%$ which was slightly less as compared to ZVI-limestone column which may be due to improved inorganic carbon supply in ZVI-limestone column. The initial degradation by limestone column was only $10 \%$ which gradually decreases, and at the end, it ceased. The removal of copper in all the three columns was up to $99.8 \%$ to $99.9 \%$. In ZVI based column the degradation was maybe due to metal sulfide precipitation. The concentration of cadmium and lead was very little in the column, so the reduction was negligible. It confirmed from the study that ZVI the slow exogenous electron donor to enhance sulfate reduction. The generation of low amount of hydrogen sulfide in the effluent is due to using of ZVI. However, limestone alone is not so much useful as compared to ZVI. Baric et al., (2012) investigated the relationship between reactive media and microorganism in $\mathrm{PRB}$ for the removal of contaminants. They performed an experiment to treat chlorinated ethanes in PRB by Coupling of polyhydroxybutyrate (PHB) and ZVI. PHB has used a carbon source for enhancing microbial degradation mechanism, increasing iron reactivity and longevity. With the formation of Volatile fatty acids (VFAs), fermentation of PHB has carried out anaerobically and thus can donate electrons for reductive dechlorination by microorganisms. Two columns designed in which the first column filled with mixture of silica sand and granulated iron and the second with Fe and $\mathrm{PHB}$. The result obtained from experiment revealed that the column with $\mathrm{Fe}$ and PHB significantly reduced chlorinated ethanes on 199 days of operation and the degradation continues after 199 days, and the contaminant completely removed from the column. But in the case of the column without PHB was lower at 199 days and after this, the column completely lost its removal efficiency. The Fe-PHB column operated under acidic condition compared to Fe-column and it observed from earlier findings that reactivity of $\mathrm{ZVI}$ is strongly affected by $\mathrm{pH}$ and the degradation rate increases with increase in acidic condition (Chen et al., 2001). A microbial and mineral progress in a zero-valent iron based permeable reactive barrier operated for a long time was carried out by (Kumar et al., 2016). A laboratory-based four column study was performed using granular zero-valent iron and micro- zero valent iron in which one was filled with a small quantity of glycerol to enhance indigenous microbial activity and another one was exposed to gamma radiation for metals and sulfate reduction. It was found out that dissolved sulfate concentration at the outlet of both the biotic column ( $\mathrm{mFe}^{0}$ and $\mathrm{gFe}^{0}$ ) decreased to nearly a nondetectable concentration of less than $2 \mathrm{mg} / \mathrm{l}$ having initial sulfate concentration of $380 \mathrm{mgL}^{-1}$ in almost 30 days. However, the concentration of dissolved sulfate concentration remains unchanged in an abiotic column in which gamma radiation was constantly exposed to the column all through the experiment. Dissolved metal concentration dropped to a nondetectable concentration in both biotic and abiotic column. The Concentration of $\mathrm{Zn}$ was to some extent higher in the biotic column because of microbial participation in the column. The Presence of anaerobic microorganism trigger exalted Fe concentration in the biotic column and afterward reduced $\mathrm{Fe}^{2+}$ concentration in the columns. The microbial species identified as $A$. ferrooxidans before incubation consistent with acidic $\mathrm{pH}$ and metal load. It was an earlier observation that these microbial populations can tolerate metal load and well adapted to reducing environment of $\mathrm{Fe}^{0}$. These can grow autotrophically using $\mathrm{H}_{2}, \mathrm{CO}_{2}$, and $\mathrm{SO}_{4}$ and the experimental observation showed the presence of $\mathrm{H}_{2}$ produced by $\mathrm{Fe}^{0}$ oxidation and $\mathrm{CO}_{2}$ in column headspace. It was evident from results that these are primarily responsible for sulfate reduction. Mineral formation observed in columns. In biotic column formation of mackinawite (FeS) and lepidocrocite $(\gamma-\mathrm{FeOOH})$ (also known as metal scavengers) was found which was consistent with microbial sulfate reduction in columns. The presence of $\mathrm{Fe}^{0}$ detected in all the columns even at the end of the experiment that showed that reactivity of $\mathrm{Fe}^{0}$ was not exhausted and completely oxidized. The clogging was 
not observed in the biotic column because the iron grains were comprehensively mixed with microbial population thereby increasing the porosity of the column. However, field application might be less precise because of the changes in characteristics of groundwater. Another kind of relation between iron and microbes has been shown by (Fang et al., 2015) in which the growth and feasibility (protein mass) of S. decolorationis S12 observed with and without application of iron. The result showed that the protein mass was twice more in culture with iron support than without iron supplement which clearly indicated that iron favors the culture growth. Due to corrosion of iron $\mathrm{H}_{2}$ so produced favors the growth and also the live/dead ratio was more in iron supplemented culture. Various analysis like SEM, TEM, CLSM, EDS indicated that direct interaction took place between iron and S12 and the strain also get attached to the surface of iron which promoted removal of contaminants. Several other species were identified like Shewanella spp., such as S. alga, S. putrefaciens and S. oneidensis, which showed attaching ability on the surface of iron minerals (Shin et al., 2007, Neal et al., 2005). It was observed that the toxicity of iron particles on microorganisms occur mainly through three pathways which includes altered organization of biological membranes and its associated parts leading to damage to DNA, increased membrane permeability, production of reactive oxygen species leading to oxidative stress. The production of more reactive oxygen species occurs under aerobic condition when $\mathrm{Fe} 0$ reacts with oxygen to produce hydrogen peroxide. It was observed that ROS production increases with increase in iron concentration.

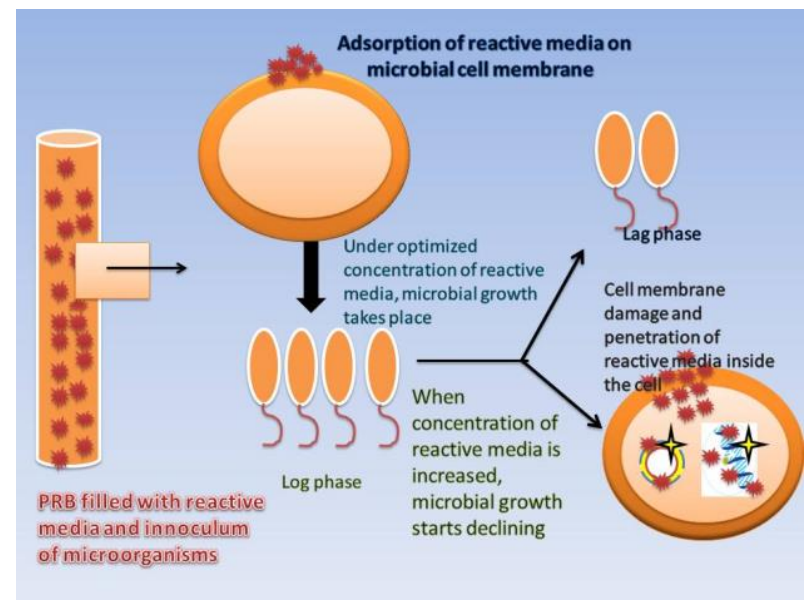

Figure 3. Interaction of reactive media and microorganism

\section{Discussion}

Since the invention of PRB from the beginning of 90's, it has proved as a creative idea behind the in-situ treatment of contaminants in groundwater at large scale. This review paper apparently deals with advancement in PRB technology, types of reactive media used with their efficiencies and limitations too, different biobarriers for the treatment, different types of microorganisms used for the biodegradation purpose, long-term performance of PRB, symbiotic relationship between microorganisms and reactive media used in $\mathrm{PRB}$. The overall study states that different reactive media have different efficiencies depending on the type of contaminant. The results also revealed that reactive media, when combined with microorganisms shows increased degradation efficiency but also exert some effect on the life cycle of microorganisms which include generation of ROS leading to oxidative stress on the cell, DNA damage, poor permeability, etc. as a result, the degradation efficiency gets slower with time. The increased types of contaminants need much more attention towards further improved treatment mechanism. However, further research may be undertaken to improve the efficiencies of bio-barriers in treating emerging pollutants and to establish various combinations of microbes and reactive media for better environmental clean-up strategies.

Acknowledgement- The authors would like to thank Ministry of Human Resource Development (MHRD) for providing facilities for conducting the research.

\section{References}

Aburto A. and Peimbert M. (2011), Degradation of a benzene toluene mixture by hydrocarbon-adapted bacterial communities, Annual Microbiology, 61(3), 553-562.

Agrawal A., Ferguson W.J., Gardner B.O., Chist J.A., Bandstra J.Z. and Tratnyek P.G. (2002), Effects of carbonate species on the kinetics of dechlorination of 1, 1, 1-trichloroethane by zerovalent iron, Environmental Science and Technology, 36,43264333.

Allison J.D., Brown D.S. and Novo-Gradac K.J. (1991), A Geochemical Assessment Model for Environmental Systems: version 3.

Anders H., Kaetzke A., Kampfer P., Ludwig W. and Fuchs G. (1995), Taxonomic Position of Aromatic-Degrading Denitrifying Pseudomonad Strains K 172 and KB 740 and Their Description as New Members of the Genera Thauera, as Thauera aromatica sp. nov., and Azoarcus, as Azoarcus evansii sp. nov., Respectively, Members of the Beta Subclass of the Proteobacteria, International Journal of Systematic Bacteriology, 45(2), 327-333.

Ayala-Parra P., Sierra-Alvarez R. and Field J.A. (2016), Treatment of acid rock drainage using a sulfate-reducing bioreactor with zero-valent iron, Journal of Hazardous Materials, 308, 97105.

Badala F., Nouri-Mahdavi K. and Raoof D.A. (2008), NIH Public Access. Computer (Long Beach Calif) 144,724-732.

Baric M. and Pierro L. (2017), Polyhydroxyalkanoate (PHB ) as a slow-release electron donor for advanced in situ bioremediation of chlorinated enhanced treatment of chlorinated ethanes in permeable reactive barriers (PRBs), Chemical Engineering Journal, 195-196, 22-30 .

Bastiaens L. (2010), Permeable Reactive Barriers \& Reactive Zones, Proceedings of the 4th International Symposium: Permeable Reactive Barriers and Reactive Zones,

Bastida F., Rosell M., Franchini A.G., Seifert J., Finsterbusch S., Jehmlich N., Jechalke S., Bergen V.M. and Richnow H.H. (2010), Elucidating MTBE degradation in a mixed consortium using a multidisciplinary approach, FEMS Microbiology Ecology, 73, 370-384.

Blázquez G., Hernáinz F., Calero M. and Tenorio G. (2009), The effect of $\mathrm{pH}$ on the biosorption of $\mathrm{Cr}$ (III) and $\mathrm{Cr}(\mathrm{VI})$ with olive stone, Chemical Engineering Journal, 148, 473-479. 
Boni M.R. and Sbaffoni S. (2009), The potential of compost-based biobarriers for $\mathrm{Cr}$ (VI) removal from contaminated groundwater: Column test, Journal of Hazardous Materials, 166, 1087-1095.

Cerniglia C.E. (1997), Fungal metabolism of polycyclic aromatic hydrocarbons: past, present and future applications in bioremediation, Journal of Industrial Microbiology and Biotechnology, 19, 324-333.

Chen J., Al-abed S.R., Ryan J.A. and Li Z. (2001), Effects of pH on dechlorination of trichloroethylene by zero-valent iron, Journal of Hazardous Materials, 83, 243-254.

Chen Y., Li J., Lei C. and Shim H. (2011), Interactions Between BTEX, TPH, and TCE During Their bio-removal from the Artificially Contaminated Water, BIONATURE 2011: The Second International Conference on Bioenvironment, Biodiversity and Renewable Energies, 33-37.

Costa F., Quintelas C. and Tavares T. (2012), Kinetics of biodegradation of diethylketone by Arthrobacter viscosus, Biodegradation, 23, 81-92.

Cavalca L., Amico D.E. and Andreoni V. (2004), Intrinsic bioremediability of an aromatic hydrocarbon-polluted groundwater: diversity of bacterial population and toluene monoxygenase genes, Applied Microbiology Biotechnology, 64, 576-587.

Diao M. and Yao M. (2009), Use of zero-valent iron nanoparticles in inactivating microbes, Water Research, 43, 5243-5251.

Erto A., Bortone I., Nardo A., Di. Natale M.D. and Musmarra D. (2014), Permeable Adsorptive Barrier (PAB) for the remediation of groundwater simultaneously contaminated by some chlorinated organic compounds, Journal of Environmental Management, 140, 111-119.

Fang Y., Xu M., Wu W., Chen X., Sun G., Guo J. and Liu X. (2015), Characterization of the enhancement of zero valent iron on microbial azo reduction, BMC Microbiology, 15(85), 1-9.

Fenton O., Healy M.G., Brennan F., Jahangir M.M.R., Lanigan G.J., Richards K.G., Thornton S.F. and Ibrahim T.G. (2014), Permeable reactive interceptors: blocking diffuse nutrient and greenhouse gases losses in key areas of the farming landscape, Journal of Agricultural Science, 152, S71-S81.

Freidman B.L., Terry D., Wilkins D., Spedding T., Gras S.L., Snape I., Stevens G.W. and Mumford K.A. (2017), Permeable bioreactive barriers to address petroleum hydrocarbon contamination at subantarctic Macquarie Island, Chemosphere, 174, 408- 420.

Ferreira L., Cobas M., Tavares T., Sanromán M.A. and Pazos M. (2013), Assessment of Arthrobacter viscosus as reactive medium for forming permeable reactive biobarrier applied to PAHs remediation, Environment Science Pollution Research, 20, 7348-7354.

Ferreira M.I.M., Marchesi J.R. and Janssen D.B. (2008), Degradation of 4-fluorophenol by Arthrobacter sp. strain IF1, Applied Microbiology Biotechnology, 78, 709-717.

Flury B., Eggenberger U. and Mäder U. (2009), First results of operating and monitoring an innovative design of a permeable reactive barrier for the remediation of chromate contaminated groundwater, Applied Geochemistry, 24, 687696.

Folch A., Vilaplana M., Amado L., Vicent T. and Caminal G. (2013), Fungal permeable reactive barrier to remediate groundwater in an artificial aquifer, Journal of Hazardous Materials, 262, $554-560$.
Fonseca B., Pazos M., Tavares T. and Sanromán M.A. (2012), Removal of hexavalent chromium of contaminated soil by coupling electrokinetic remediation and permeable reactive biobarriers, Environment Science Pollution Research, 19, 1800-1808.

Hana W., Fu F., Cheng Z., Tanga B. and Wu S. (2016), Studies on the optimum conditions using acid-washed zero-valent iron/aluminum mixtures in permeable reactive barriers for the removal of different heavy metal ions from wastewater, Journal of Hazardous Materials, 302, 437-446.

Healy M.G., Ibrahim T.G., Lanigan G.J., Serrenhoa A.J. and Fenton O. (2012), Nitrate removal rate, efficiency and pollution swapping potential of different organic carbon media in laboratory denitrification bioreactors, Ecological Engineering, 40, 198-209.

Henderson A.D. and Demond A.H. (2007), Long-Term Performance of Zero-Valent Iron Permeable Reactive Barriers: A Critical Review, Environmental Engineering Science, 24, 401-423.

Huang G., Huang Y., Hu H., Liu F., Zhang Y. and Deng R. (2015), Remediation of nitrate-nitrogen contaminated groundwater using a pilot-scale two-layer heterotrophic-autotrophic denitrification permeable reactive barrier with spongy iron/pine bark, Chemosphere, 130, 8-16.

Hyman M. (2013), Biodegradation of gasoline ether oxygenates, Current Opinion in Biotechnology, 24, 443-450.

ITRC (2011), Permeable Reactive Barrier: Technology Update PRB5, Interstate Technology Regulatory Council, 1-234.

Jeen S.W., Gillham R.W. and Przepiora A. (2011), Predictions of long-term performance of granular iron permeable reactive barriers: Field-scale evaluation, Journal of Contaminant Hydrology, 123, 50-64.

Jeen S.W., Mayer K.U., Gillham R.W. and Blowes D.W. (2007), Reactive transport modeling of trichloroethene treatment with declining reactivity of iron, Environmental Science and Technology, 41, 1432-1438.

Kalinovich I.K., Rutter A., Rowe R.K. and Poland J.S. (2012), Design and application of surface PRBs for PCB remediation in the Canadian Arctic, Journal of Environmental Management, 101, 124-133.

Karigar C., Mahesh A., Nagenahalli M. and Yun D.J. (2006), Phenol degradation by immobilized cells of Arthrobacter citreus, Biodegradation, 17, 47-55.

Kasi M., Wadhawan T., Simsek H., McEvoyc J., Padmanabhana G., Sletten D. and Khan E. (2013), Enricher reactor - Permeable reactive biobarrier approach for removing a mixture of contaminants with substrate interactions, Bioresource Technology, 146, 336-344.

Kim J.M., Le N.T., Chung B.S., Park J.H., Bae J.W., Madsen E.L. and Jeon C.O. (2008), Influence of soil components on the biodegradation of benzene, toluene, ethylbenzene, and o-, m, and p-xylenes by the newly isolated bacterium Pseudoxanthomonas spadix BD-a59, Applied and Environmental Microbiology, 74,7313-7320.

Klankeo P., Nopcharoenkul W. and Pinyakong O. (2009), Two novel pyrene-degrading Diaphorobacter sp. and Pseudoxanthomonas $s p$. isolated from soil, Journal of Bioscience and Bioengineering, 108, 488-495.

Klausen J., Vikesland P.J., Kohn T., Burris D.R., Ball W.P. and Roberts A.L. (2003), Longevity of granular iron in groundwater treatment processes: Solution composition effects on 
reduction of organohalides and nitroaromatic compounds, Environmental Science and Technology, 37, 1208-1218.

Kleinsteuber S., Schleinitz K.M. and Vogt C. (2012), Key players and team play: Anaerobic microbial communities in hydrocarbon-contaminated aquifers, Applied Microbiology Biotechnology, 94, 851-873.

Kober R., Schäfer D., Erbert M. and Dahmke A. (2002), Coupled in situ reactors using $\mathrm{Fe} 0$ and activated carbon for the remediation of complex contaminant mixtures in groundwater, Proceeding Groundwater Quality, 275, 435518.

Kumar N., Chaurand P., Rose J., Diels L. and Bastiaens L. (2015), Synergistic effects of sulfate reducing bacteria and zero valent iron on zinc removal and stability in aquifer sediment, Chemical Engineering Journal, 260, 83-89.

Kumar N., Millot R., Battaglia-Brunet F., Omoregie E., Chaurand P., Borschneck D., Bastiaens L. and Rose J. (2016), Microbial and mineral evolution in zero valent iron-based permeable reactive barriers during long-term operations, Environment Science Pollution Research, 23, 5960-5968.

Lameiras S., Quintelas C. and Tavares T. (2008), Biosorption of $\mathrm{Cr}$ (VI) using a bacterial biofilm supported on granular activated carbon and on zeolite, Bioresource Technology, 99, 801-806.

Lapointe F., Fytas K. and McConchie D. (2006), Efficiency of Bauxsol $^{\mathrm{TM}}$ in permeable reactive barriers to treat acid rock drainage, Mine Water Environment, 25, 37-44.

Lee J.Y., Moon C.H., Kim J.H. and Oh B.T. (2007), Feasibility study of the bio-barrier with biologically-active tire rubbers for treating chlorinated hydrocarbons, Geosciences Journal, 11(2), 131- 136.

Li L. and Goel R. (2012), Biodegradation of naphthalene, benzene, toluene, ethyl benzene, and xylene in batch and membrane bioreactors, Environment Engineering Science, 29, 42-51.

Li R., Feng C., Hu W., Xi B., Chen N., Zhao B., Liu Y., Hao C. and Puet J. (2016), Woodchip-sulfur based heterotrophic and autotrophic denitrification (WSHAD) process for nitrate contaminated water remediation, Water Research, 89, 171179.

Li Y.N., Porter A.W., Mumford A., Zhao X.H. and Young L.Y. (2012), Bacterial community structure and bamA gene diversity in anaerobic degradation of toluene and benzoate under denitrifying conditions, Journal of Applied Microbiology, 112, 269-279.

Liu Y., Mou H., Chen L., Mirzad Z.A. and Liu L. (2015), Cr (VI)contaminated groundwater remediation with simulated permeable reactive barrier (PRB) filled with natural pyrite as reactive material: Environmental factors and effectiveness, Journal of Hazardous Materials, 298, 83-90.

López E., Ramos I. and Sanromán M.A. (2003), Extracellular polysaccharides production by Arthrobacter viscosus, Journal of Food Engineering, 60, 463-467.

Mackay D.M., Wilson R.D., Naas C., Wood I., Scow K., Smith A., Gandhi D., Hristova K., Watanabe B. and Einarson M. (2002), In situ treatment of MTBE-contaminated groundwater at two sites in California, IAHS-AISH Publication, 333-340.

Marco-Urrea E., Gabarrell X., Sarrà M., Caminal G., Vicent T. and Reddy C.A. (2006), Novel aerobic perchloroethylene degradation by the white-rot fungus Trametes versicolor, Environmental Science and Technology, 40, 7796-7802.

Martin F., Torelli S., Le Paslier D., Barbance A., Laurent F.M., Bru D., Geremia R., Blake G. and Jouanneau Y. (2012),
Betaproteobacteria dominance and diversity shifts in the bacterial community of a PAH-contaminated soil exposed to phenanthrene, Environmental Pollution, 162, 345-353.

Mondal P.K., Lima G., Zhang D., Lomheimb L., Tossell R.W., Patel P. and Sleep B.E. (2016), Evaluation of peat and sawdust as permeable reactive barrier materials for stimulating in situ biodegradation of trichloroethene, Journal of Hazardous Materials, 313, 37-48.

Moraci N. and Calabro P.S. (2010), Heavy metals removal and hydraulic performance in zero-valent iron/pumice permeable reactive barriers, Journal of Environmental Management, 91, 2336-2341.

Morkin M., Devlin J.F., Barker J.F. and Butler B.J. (2000), In situ sequential treatment of a mixed contaminant plume, Journal of Contaminant Hydrology, 45, 283-302.

Mumford K.A., Rayner J.L., Snape I. and Stevens G.W. (2014), Hydraulic performance of a permeable reactive barrier at Casey Station, Antarctica, Chemosphere, 117, 223-231.

Neal A.L., Bank T.L., Hochella M.F. and Rosso K.M. (2005), Cell adhesion of Shewanella oneidensis to iron oxide minerals: Effect of different single crystal faces, Geochemical Transactions, 6, 77-84.

Noubactep C. (2010), The fundamental mechanism of aqueous contaminant removal by metallic iron, Water SA, 36, 663-670.

Obiri-Nyarko F., Grajales-Mesa S.J. and Malina G. (2014), An overview of permeable reactive barriers for in situ sustainable groundwater remediation, Chemosphere, 111, 243-259.

Oztürk Z., Tansel B., Katsenovich Y., Sukop M. and Laha S. (2012), Highly organic natural media as permeable reactive barriers: TCE partitioning and anaerobic degradation profile in eucalyptus mulch and compost, Chemosphere, 89, 665-671.

Pagnanelli F., Cruz Viggi C., Cibati A., Uccellettib D., Toroa L. and Pallescheti C. (2012), Biotreatment of $\mathrm{Cr}$ (VI) contaminated waters by sulphate reducing bacteria fed with ethanol, Journal of Hazardous Materials, 199-200, 186-192.

Panturu E, Filcencu-Olteanu A., Groza N., Panturu R.I. and Ciobanu L. (2009), Uranium Immobilization on Reactive Material Using RPB, Chemical Bull "POLITEHNICA" Univ Timisoara, 54, 50-53.

Parkhurst B.D.L. and Appelo C.A.J. (1999), User's Guide To PHREEQC (version 2) - a Computer Program for Speciation, and Inverse Geochemical Calculations. Exch Organ Behav Teach J D:326. doi: Rep. 99-4259

Patel V., Cheturvedula S. and Madamwar D. (2012), Phenanthrene degradation by Pseudoxanthomonas sp. DMVP2 isolated from hydrocarbon contaminated sediment of Amlakhadi canal, Gujarat, India, Journal of Hazardous Materials, 201202, 43-51.

Pazos M., Branco M., Neves I.C., Sanromán M.A. and Tavares T. (2010), Removal of $\mathrm{Cr}(\mathrm{VI})$ from aqueous solutions by a bacterial biofilm supported on zeolite: Optimisation of the operational conditions and scale-up of the bioreactor, Chemical Engineering Technology, 33, 2008-2014.

Perić J., Trgo M. and Vukojević Medvidović N (2004), Removal of zinc, copper and lead by natural zeolite - A comparison of adsorption isotherms, Water Research, 38,1893-1899.

Quintelas C., Silva B., Figueiredo H. and Tavares T. (2010), Removal of organic compounds by a biofilm supported on GAC: Modelling of batch and column data, Biodegradation, 21, 379-392. 
Raynal M. and Pruden A. (2008), Aerobic MTBE biodegradation in the presence of BTEX by two consortia under batch and semibatch conditions, Biodegradation, 19, 269-282.

Rodak C., Silliman S.E. and Bolster D. (2014), Time-dependent health risk from contaminated groundwater including use of reliability, resilience and vulnerability as measures, Journal of American Water Resource Association, 50, 14-28.

Ruhl A.S., Ünal N. and Jekel M. (2013), Combination of Fe (0) with additional reactive materials in fixed bed reactors for TCE removal, Chemical Engineering Journal, 222,180-185.

Schipper L.A., Robertson W.D., Gold A.J., Jaynes D.B. and Cameron S.C. (2010), Denitrifying bioreactors-An approach for reducing nitrate loads to receiving waters, Ecological Engineering, 36, 1532-1543.

Shin H.Y., Singhal N. and Park J.W. (2007), Regeneration of iron for trichloroethylene reduction by Shewanella alga $\mathrm{BrY}$, Chemosphere, 68, 1129-1134.

Simon F.G. and Meggyes T. (2000), Removal of organic and inorganic pollutants from groundwater using permeable reactive barriers, Land Contamination and Reclamation, $\mathbf{8}$, 103-116.

Stevens C.J. and Quinton J.N. (2009), Diffuse Pollution Swapping in Arable Agricultural Systems, Critical Review in Environmental Science and Technology, 39, 478-520.

Suk O.J., Jeen S.W., Gillham R.W. and Gui L. (2009), Effects of initial iron corrosion rate on long-term performance of iron permeable reactive barriers: Column experiments and numerical simulation, Journal of Contaminant Hydrology, 103, 145-156.

Teerakun M., Reungsang A., Lin C.J. and Liao C.H. (2011), Coupling of zero valent iron and biobarriers for remediation of trichloroethylene in groundwater, Journal of Environmental Science, 23, 560-567.

Thiruvenkatachari R., Vigneswaran S. and Naidu R. (2008), Permeable reactive barrier for groundwater remediation, Journal of Industrial and Engineering Chemistry, 14, 145-156.

Tiehm A., Müller A., Alt S., Jacob H., Schad H. and Weingran C. (2008), Development of a groundwater biobarrier for the removal of polycyclic aromatic hydrocarbons, BTEX, and heterocyclic hydrocarbons, Water Science and Technology, 58, 1349-1355.

Vesela L., Nemecek J., Siglova M. and Kubal M. (2006), The biofiltration permeable reactive barrier: Practical experience from Synthesia, International Biodeterioration and Biodegradation, 58, 224-230.

Wang Y., Pleasant S., Jain P., Powell J. and Townsend T. (2016), Calcium carbonate-based permeable reactive barriers for iron and manganese groundwater remediation at landfills, Waste Management, 53, 128-135.

Wang Y., Sikora S. and Townsend T.G. (2013), Ferrous iron removal by limestone and crushed concrete in dynamic flow columns, Journal of Environmental Management, 124, 165171.

Waybrant K.R., Ptacek C.J. and Blowes D.W. (2002), Treatment of mine drainage using permeable reactive barriers: Column experiments, Environmental Science and Technology, 36, 1349-1356.

Wen Y.J., Yang Y.S., Ren H.J., Dua X.Q., Yangb X.Y., Zhang L.Y. and Wang X.S. (2015), Chemical-biological hybrid reactive zones and their impact on biodiversity of remediation of the nitrobenzene and aniline contaminated groundwater, Chemical Engineering Journal, 280, 233-240.

Wiafe S., Ofosu S.A. and Ahima J. (2014), The quality of groundwater resources around auto-mechanic workshop enclaves in Ghana, Health, Safety and Environment, 2(1), 1223.

Wilkin R.T., Acree S.D., Ross R.R., Puls R.W., Lee T.R. and Woods L.L. (2014), Fifteen-year assessment of a permeable reactive barrier for treatment of chromate and trichloroethylene in groundwater, Science of the Total Environment, 468-469, 186-194.

Yang J., Cao L., Guo R. and Jia J. (2010), Permeable reactive barrier of surface hydrophobic granular activated carbon coupled with elemental iron for the removal of 2,4-dichlorophenol in water, Journal of Hazardous Materials, 184, 782-787.

Yeh C.H., Lin C.W. and Wu C.H. (2010), A permeable reactive barrier for the bioremediation of BTEX-contaminated groundwater: Microbial community distribution and removal efficiencies, Journal of Hazardous Materials, 178, 74-80.

Yin W., Wu J., Huang W. and Wei C. (2015), Enhanced nitrobenzene removal and column longevity by coupled abiotic and biotic processes in zero-valent iron column, Chemical Engineering Journal, 259, 417-423. 